\title{
THE PERILS OF CONCEPTUALISM: A RESPONSE TO PROFESSOR FALLON
}

\author{
Robert C. Post ${ }^{*}$
}

I am grateful for Professor Fallon's constructive and lucid remarks. They are thoughtful and perceptive. But they also reveal the limitations of the kind of highly conceptualist focus that has unfortunately come to characterize so much of our modern constitutional scholarship.

Fallon argues that what I identify as the "paradox of public discourse" can be dissolved if first amendment doctrine is conceived within the framework of Rawlsian liberalism. He contends that from the perspective of that liberalism, members of a particular community "can believe that behavior is outrageous and therefore reprehensible while simultaneously believing, as members of a national community, ... that their own illiberal moral norms ought not to enjoy the sanction of law." "If this is so," Fallon concludes, "denying the sanction of law to . . . illiberal norms does not corrode the necessary foundation [of] liberal norms for critical public discourse to occur. There is, in short, no paradox." 2

Fallon is, of course, quite correct that there is no logical inconsistency between the existence of community norms and the need for public toleration. But the limitations of this point become obvious as soon as it is seen that law does not exist merely on the conceptualist plane of logic and theory, but serves also as a practical instrument for the governance of society. The "paradox of public discourse" does not flow from the incompatibility of abstract ideas, but rather from the sociological tensions inherent in the dynamic functioning of the law.

On Rawls' account, the purpose of public toleration is to provide a foundation for "political cooperation on a basis of mutual respect." 3 This purpose, as Rawls remarks, "is practical, and not metaphysical or epistemological." 4 It can be served only if public discussion is "informed and uncoerced, and reached by citizens in ways consistent with their being viewed as free and equal persons." Rawls' account,

\footnotetext{
* Professor of Law, University of California at Berkeley (Boalt Hall).

${ }^{1}$ Fallon, Post on Public Discourse Under the First Amendment, I03 HARv. L. Rev. I738, I74I (I 990).

2 Id.

${ }^{3}$ Rawls, Justice as Fairness: Political not Metaphysical, 14 PHIL. \& PUB. AfF. 223, 226 (1985).

4 Id. at 230 .

5 Id. at $229-30$.
} 
therefore, unlike Fallon's, directly raises the question of the practical relationship between toleration and the attainment of "willing political agreement." 6

The argument of my Article is that the social ability to distinguish "coercion" from "respect" is ultimately grounded on community norms (of the kind that Fallon too quickly labels as "illiberal"), ${ }^{7}$ and that the survival of these norms is in some significant measure sustained by legal sanctions. If these arguments are correct, it follows that public toleration is in tension with itself, for it denies enforcement to the very legal sanctions that sustain the social norms necessary for public toleration to achieve its purposes. The evidence for these arguments is sociological in nature; the argument of the Article thus cannot be dismissed because of the absence of any purely conceptual inconsistency between community norms and public toleration.

To put the matter more aggressively, it is not enough simply to postulate citizens who can, as Rawls puts it, have "their public identity" as well as "their "nonpublic identity." 8 We need to inquire into how these two identities in fact relate to each other; we must investigate the nature and potential limits of the stark role differentiation implicit in Rawls' theory. We must ask about the kind of "political cooperation" that would actually be possible among persons who claim, as does Fallon, that the very norms that fundamentally define and sustain their dignity as human beings ought not to be enforced by the law, because these norms might not be shared by others. ${ }^{9}$ If philosophers can afford to ignore these hard, practical questions, we as legal academics cannot.

Rawls himself explicitly rests his work on what he calls "a normative conception" of "the person," which is distinct "from an account of human nature given by natural science or social theory."10 My hypothesis is that the notoriously ragged edges of first amendment doctrine can best be interpreted as the Court's efforts to address the tensions that occur when this "normative conception" of the person is

\footnotetext{
6 Id. at 230.

${ }^{7}$ Note, in this context, Rawls' concession that public toleration can have meaning only if it "provides a reasonable way of shaping into one coherent view the deeper bases of agreement embedded in the public political culture of a constitutional regime and acceptable to its most firmly held considered convictions." Id. at 229. For a detailed account of how a putatively "illiberal" culture creates normative distinctions that make possible putatively "liberal" concepts like respect and individual autonomy, see Post, The Social Foundations of Privacy: Community and Self in the Common Law Tort, 77 CALIF. L. REv. 957, 968-74, 979-87 (1989).

8 Rawls, supra note 3 , at $24 \mathrm{I}$.

${ }^{9}$ Rawls himself offers the caveat that "we are forced to consider at some point the effects of the social conditions required by a conception of political justice on the acceptance of that conception itself." Id. at 250.
}

10 Id. at 232 n. I 5 . 
evaluated in light of the account of human nature given by "social theory."

I should also add, however, that I see much that is attractive, on both theoretical and practical levels, in the Rawlsian account. In this respect Fallon's conceptualist and ultimately procrustean division of theories into "republican" and "liberal" is of little use, and of some detriment. Human nature is obviously capable of and predicated upon both the autonomy that underlies liberalism and the social embeddedness that underlies what Fallon terms republicanism. The issue is therefore not whether one perspective or the other should be chosen tout court, but rather whether, in the complex of particular circumstances, the law ought to be designed to support one or the other of these human capabilities. ${ }^{11}$

Thus, despite the internal tensions of the position, I agree wholeheartedly with Rawls that structuring public discourse around the values of toleration and respect for individual freedom offers a compelling vision of "how social unity can be . . . possible" 12 under conditions of cultural heterogeneity. In my Article I try to elucidate how this vision is in fact responsible for the manner in which modern first amendment jurisprudence regulates public discourse. ${ }^{13}$

I share this vision, however, with a chastened sense of its internal inconsistencies, and also with a strong belief in its inherent limitations. There are circumstances in which speech ought to be regulated according to principles quite distinct from those that underlie public discourse. To offer only an obvious example, speech that is appropriately protected when it occurs within public discourse is also appropriately regulated as racial or sexual harassment when it occurs within the context of an employment relationship. This is true because there are good reasons for the law to regard persons as autonomous within the context of political deliberation, but there are equally good reasons for the law to regard persons as dependent within the workplace.

If this confounds the ready distinction between liberalism and

11 For a somewhat fuller account, see Post, Tradition, the Self, and Substantive Due Process: A Comment on Michael Sandel, 77 CALIF. L. REv. 553, 558-59 (1989).

12 Rawls, supra note 3 , at $25 \mathrm{I}$.

13 Thus I am somewhat puzzled by Fallon's claim that I attempt to ascribe "republican premises" to first amendment jurisprudence. It is surely not distinctively "republican" to assume that the purpose of public discourse is "the promotion of public deliberation," for Rawls himself states that the "aim" of his liberalism "is free agreement, reconciliation through public reason." Id. at 230. Nor is it especially "republican" to assume that public deliberation cannot be successful if it is experienced as coercive, for once again Rawls himself notes "that this agreement must be informed and uncoerced, and reached by citizens in ways consistent with their being viewed as free and equal persons." Id. at 229-30. 
republicanism, so be it. We ought not let these categories harden to the point where they obstruct our perception of what really matters, which is how the legal order may practically assist the flourishing of the human spirit. 